\title{
DEVELOPING THE CRIME OF PUBLIC VIOLENCE AS A REMEDY TO THE VIOLATION OF THE RIGHTS OF NON-PROTESTERS DURING VIOLENT PROTESTS AND STRIKES - A CRITICAL ANALYSIS OF THE SOUTH AFRICAN JURISPRUDENCE*
}

Khulekani Khumalo

LLB

Attorney of the High Court

\section{SUMMARY}

While section 17 of the Constitution guarantees the right to freedom of assembly, the violence that accompanies the exercise of this right often culminates in the violation of the rights of non-protesters to, inter alia, life, dignity, equality and freedom and security of the person. The crime of public violence is the primary measure in place for the maintenance of the community's interest in public peace and order, as well as for affording protection against the invasion of the rights of other people during protests and strikes. Therefore, the apparent failure of the crime to adequately safeguard the rights of non-protesters begs the question whether the crime falls short of the objectives of section 39(2) of the Constitution and thus requires to be developed in order to promote the spirit, purport and objects of the Bill of Rights. If so, how must the development take place in order to meet these objectives? Addressing the foregoing questions invariably leads to an assessment of the jurisprudential direction the South African courts are likely to take in the question of developing the crime of public violence as a remedy to the erosion of various rights of non-protesters during violent protests and strikes.

\section{INTRODUCTION}

The rise in violent service-delivery protests and strikes ${ }^{1}$ has become one of the most popular talking points in South Africa. These violent protests and

This article is based on a study conducted by the author in fulfilment of the requirements of the degree of Master of Laws. The article is essentially a breakdown or summary of the dissertation, hence it mirrors the dissertation in many respects, especially in terms of structure, pattern and wording.

1 For crime statistics reflecting an upward trend in the prevalence of violent protests and strikes in South Africa, see Khumalo Re-opening the Debate on Developing the Crime of 
strikes begin harmlessly as part of the exercise of the right to freedom of assembly which is enshrined in section 17 of the Constitution. ${ }^{2}$ Section 17 provides that "[e]veryone has the right, peacefully and unarmed, to assemble, to demonstrate, to picket and to present petitions". However, the violence that often accompanies the exercise of this right culminates in the violation of the rights of non-protesting members of the community or nonstriking workers ("non-protesters") to, inter alia, equality, dignity, life, as well as freedom and security of the person. ${ }^{3}$ In the midst of the violence and the consequent violation of the rights of non-protesters, the common-law crime of public violence ${ }^{4}$ is the primary measure ${ }^{5}$ in place for the maintenance of the community's interest in public peace and order, ${ }^{6}$ as well for affording protection against the violation of the rights of other people. ${ }^{7}$ It is for this reason that the crime of public violence finds itself at the centre of the protest- and strike-violence debacle, alongside other issues such as the policing of protests.

Public Violence in Light of the Violent Protests and Strikes (Unpublished master's dissertation, University of KwaZulu-Natal 2015) 9-16.

2 The Constitution of the Republic of South Africa, 1996.

3 See s 9-12 of the Constitution respectively. The right to equality is implicated when, for instance, the perpetrators of violence are not prosecuted for their deeds, thus resulting in non-protesters not being afforded the right to equal protection and benefit of the law. The right to human dignity is implicated when non-protesters' right to freedom of choice is disregarded and they are forced to join a protest or a strike against their will. It is also implicated when non-protesters are assaulted and subjected to various types of humiliating conduct in public. The right to life is implicated when non-protesters are actually killed by the protesting mob for their non-participation in the protest or a strike, or face threats of being killed as a means to persuade them to join the protest or a strike. The acts of intimidation, assault and other acts of violence directed at non-protesters impact adversely on their right to freedom and security of the person.

There are other rights of non-protesters which may be implicated depending on the facts of each case. The above-named rights do not constitute a closed list. For instance, where a violent protest or a strike is accompanied by the looting of businesses, the right to freedom of trade (s 22 of the Constitution) and the right not to be deprived of property arbitrarily (s 25 of the Constitution) may be implicated. Furthermore, where journalists are assaulted and prevented from carrying out their duties, the right to free press may be implicated.

4 By definition, public violence consists in the unlawful and intentional commission by a number of people acting in concert of acts of sufficiently serious dimensions that are intended to forcibly disturb the public peace or security or to invade the rights of others Burchell Principles of Criminal Law 4ed (2013) 755. For a summary of the development of the crime of public violence from its inception to date, see Khumalo Re-opening the Debate on Developing the Crime of Public Violence in Light of the Violent Protests and Strikes 2445 .

5 There are other common-law crimes (such as assault, malicious damage to property, arson and robbery) and statutory offences (such as those created in $s 12$ of the Regulation of Gatherings Act 205 of 1993) with which the crime of public violence overlaps, but the dangerous dimensions assumed by the conduct of the protesting crowd warrant that the offenders be charged with a more serious crime, and that is public violence - see Snyman Criminal Law 6ed (2014) 312. Furthermore, there are also civil remedies (provided for in terms of the common law and s 11 of the RGA) which exist alongside the crime of public violence.

6 Burchell Principles of Criminal Law 755. Burchell further contends that the crime of public violence provides a legal remedy for the abuse of the right to gather and demonstrate.

7 See Skeen "Criminal Law" in Joubert The Law of South Africa Vol VI 2ed (2010) par 11. The writer explains that the interest protected by a particular crime can be deduced from the definition of that crime. Therefore, judging from the definition of the crime of public violence, the crime is also aimed at affording protection against the invasion of the rights of other people. 
The subject of contention, on which the present paper focuses, implicating the crime of public violence in this debacle is that the extent of the violation of the rights of non-protesters during violent protests and strikes without any significant legal repercussions for the perpetrators raises a concern as to the ability of the crime to adequately safeguard the rights of non-protesters. Consequently, the question arises as to whether the apparent failure of the crime of public violence to adequately safeguard the rights of non-protesters ${ }^{8}$ means that the crime falls short of the objectives of section 39(2) of the Constitution and thus requires to be developed in order to promote the spirit, purport and objects of the Bill of Rights. If so, how must the development take place in order to meet these objectives? The purpose of this paper, in addressing the above question, is to examine the jurisprudential direction the South African courts are likely take in the question of developing the crime of public violence as a remedy to the erosion of the rights of non-protesters. Therefore, a critical analysis of the various academic views, relevant arguments/opinions both in favour and against the development of the crime, case law and other authority in point is undertaken in order to achieve the object of this paper.

\section{BACKGROUND}

The court in $S v$ Thebus $^{9}$ held that the need to develop the common law arises at least in two instances. The first is when a common-law rule/provision is inconsistent with the Constitution, and the second is when a common-law rule/provision is consistent with the Constitution, but falls short of its spirit, purport and objects. The present paper is concerned with the latter. In Carmichele v Minister of Safety and Security, ${ }^{10}$ the court expressed the following with regard to developing a common-law rule/provision that is consistent with the Constitution, but falls short of its spirit, purport and objects:

"In such a situation there are two stages to the inquiry a court is obliged to undertake. They cannot be hermetically separated from one another. The first stage is to consider whether the existing common law, having regard to the $s$ $39(2)$ objectives, requires development in accordance with these objectives.

This inquiry requires a reconsideration of the common law in the light of $s$ 39(2). If this inquiry leads to a positive answer, the second stage concerns itself with how such development is to take place in order to meet the s 39(2) objectives."

Generally, the courts have a duty to develop the common law and they may proceed to develop the common law of their own accord without being specifically requested by the parties to the dispute to do so. ${ }^{11}$ Developing the common law in light of section 39(2) of the Constitution ensures that the

8 The reasons for the allegation that the crime of public violence is failing to adequately safeguard the rights of non-protesters are set out in par 4 below.

92003 (6) SA 505 (CC) par 28.

102001 (4) SA 938 (CC) par 40. This judgment has since been approved and applied in subsequent cases. For instance, see K v Minister of Safety and Security 2005 (6) SA 419 (CC) in regard to the development of vicarious liability principles. See further Masiya $v$ Director of Public Prosecutions, Pretoria 2007 (5) SA 30 (CC) in regard to the development of the crime of rape.

11 Carmichele $v$ Minister of Safety and Security supra par 39. 
common law is "adapted so that it grows in harmony with the objective normative value system found in the Constitution". ${ }^{12}$ Thus, the purpose of section 39(2) is to instil the values of the Constitution throughout the common law, and the procedure in so doing simply entails that the commonlaw principles be understood and applied within the normative framework of the Constitution. ${ }^{13}$

Before I turn to deal with the inquiry set out in Carmichele $v$ Minister of Safety and Security ${ }^{14}$ case as it pertains to the crime of public violence, it is best to first summarise the Constitutional Court case of SATAWU $v$ Garvas. ${ }^{15}$ This case, being the leading pronouncement by the Constitutional Court on the right to freedom of assembly, provides an indication of South Africa's current assembly jurisprudence in light of the growing pattern of violent protests and strikes sweeping across the country. The jurisprudential articulations outlined in this case provide some insight into the court's likely attitude towards developing the crime of public violence, or at least an indication of how the court would reason in a matter of this nature. Furthermore, the arguments advanced in SATAWU $\vee$ Garvas could be used in arguing for and against the development of the crime of public violence.

\section{SATAWU V GARVAS 2013 (1) SA 83 (CC)}

During the course of a protracted strike led by the South African Trade and Allied Workers Union (SATAWU) which had already seen about 50 people being killed as well as massive damage to property, SATAWU convened a march of thousands of people in the city of Cape Town to present the demands of the workers in the security industry. SATAWU had complied with all the procedural requirements of the Regulation of Gatherings $\mathrm{Act}^{16}$ (RGA) and had taken several steps to prevent riot damage from occurring. Despite these preventative measures, the march turned into a full-scale riot and property to the value of R1.5 million was damaged. The victims of riot damage, most of whom being business owners as well as persons with a financial interest in the vehicles damaged during the riot, instituted legal action against SATAWU in terms of section 11(1) of the RGA ${ }^{17}$ and, alternatively, in terms of the common law for damages suffered.

12 Currie and De Waal The Bill of Rights Handbook 6ed (2005) 61, quoting Carmichele v Minister of Safety and Security supra par 54. See also De Vos et al South African Constitutional Law in Context (2014) 343; and S v Thebus supra par 27.

3 V Minister of Safety and Security supra par 17 and 23.

14 See fn 10 above.

152013 (1) SA 83 (CC).

6205 of 1993.

$17 \mathrm{~S} 11(1)$ of the RGA holds the organisers or conveners of gatherings as well as the participants in demonstrations jointly and severally liable for riot damage arising from the said gatherings or demonstrations. To ameliorate the effect of $s$ 11(1), s 11(2) provides a statutory defence as follows: "[i]t shall be a defence to a claim against a person or organisation contemplated in subsection (1) if such a person or organisation proves - (a) that he or it did not permit or connive at the act or omission which caused the damage in question; and (b) that the act or omission in question did not fall within the scope of the objectives of the gathering or demonstration in question and was not reasonably foreseeable; and (c) that he or it took all reasonable steps within his or its power to prevent the act or omission in question: provided that proof that he or it forbade an act of the kind in 
SATAWU denied liability and contended that the words "and was not reasonably foreseeable" in section 11(2)(b) of the RGA render the statutory defence against the imposition of civil liability for riot damage created in section 11(1) internally destructive and irrational, and therefore unconstitutional. The irrationality was argued to emanate from the wording of subsections (b) and (c) of section 11(2) which effectively require, on the one hand, that the organiser of a gathering proves that the act or omission which led to riot damage was not foreseeable, and, on the other hand, that it (the organiser) took reasonable steps to guard against the act or omission that was not reasonably foreseeable. SATAWU also argued that section 11(2) of the RGA had a "chilling effect" on the exercise of the right to freedom of assembly, therefore it unjustifiably limits the said right. The Respondents (Claimants/Plaintiffs in the High Court) argued that the right to freedom of assembly was not applicable in the present case because the march in question had not been "peaceful". They argued that the right in section 17 of the Constitution only applies to gatherings and demonstrations that are "peaceful and unarmed".

SATAWU's challenge failed in the High Court ${ }^{18}$ and in the Supreme Court of Appeal. ${ }^{19}$ In deciding on the rationality of the defence created in section 11(2) of the RGA, the majority of the Constitutional Court, per Mogoeng CJ, held that it is a long-standing principle that if an impugned statutory provision is capable of a rational interpretation which is within the bounds of the Constitution, then the provision must be afforded that interpretation so to preserve its constitutional validity and preserve the purpose of the provision. ${ }^{20}$ In this regard, the court reasoned that the intention of the legislature by enacting section 11 of the RGA was to hold the organisations liable for their decision to hold gatherings and demonstrations. ${ }^{21}$

The effect of such liability was alleviated by the creation of a statutory defence in section 11(2). Therefore, by imposing civil liability on organisers of gatherings and demonstrations, and also providing a defence thereto, Parliament sought (i) to create statutory liability of organisations, so as to avoid the common-law difficulties associated with proving the existence of a legal duty on the organisation to avoid harm; (ii) to afford the organiser a tighter defence, allowing it to rely on the absence of reasonable foreseeability and the taking of reasonable steps as a defence to the imposition of liability; and (iii) to place the onus on the Defendant to prove this defence, instead of requiring the Plaintiff to demonstrate the Defendant's wrongdoing and fault. ${ }^{22}$

The court then concluded that the irrationality of the defence would be avoided if the whole of section 11(2) is taken together and understood as requiring that reasonable steps within the power of the organiser be taken to

question shall not by itself be regarded as sufficient proof that he or it took all reasonable steps to prevent the act in question".

18 The decision of the High Court is reported as Garvis v SATAWU 2010 (6) SA 280 (WCC).

19 The decision of the Supreme Court of Appeal the case is reported as SATAWU $\checkmark$ Garvis 2011 (6) SA 382 (SCA).

20 Par 37.

21 Par 38.

22 Par 39. 
guard against an act or omission that is reasonably foreseeable. ${ }^{23}$ Therefore, if the steps so taken were reasonable to prevent what was foreseeable, then the act or omission subsequently giving rise to riot damage would not have been foreseeable and the organiser would not be liable.

On the issue of whether section 11(2) limits the right to freedom of assembly and whether the limitation is justifiable, the majority of the Constitutional Court rejected the finding of the High Court and the Supreme Court of Appeal that the right in section 17 of the Constitution was not implicated at all in the present case because the existence of riot damage meant that the march had not been peaceful. In this regard, the court ${ }^{24}$ expressed that:

"Nothing said thus far detracts from the requirement that the right in section 17 must be exercised peacefully. And it is important to emphasise that it is the holders of the right who must assemble and demonstrate peacefully. It is only when they have no intention of acting peacefully that they lose their constitutional protection."

The court cited with approval the dictum of the European Court of Human Rights in Zilberberg $v$ Moldova (ECHR Application No 61821/00; 4 May 2004) par [2] to the effect that:

"[A]n individual does not cease to enjoy the right to peaceful assembly as a result of sporadic violence or other punishable acts committed by others in the course of the demonstration, if the individual in question remains peaceful in his or her own intentions or behaviour."

The court then went on to consider how the right to freedom of assembly was limited by section 11(2) of the RGA. It found that the section limited the right in two ways. First, compliance with section 11(2) requirements significantly increases the cost of organising a demonstration, and, second, it had the effect of inhibiting particularly those poorly-resourced organisations from organising demonstrations in order to express their views on pressing societal issues. ${ }^{25}$ However, upon engaging the inquiry in terms of section 36 of the Constitution, the court found that the limitation was reasonable and justifiable in an open and democratic society based on human dignity, equality and freedom.

On the importance of the right to freedom of assembly, the court expressed that: ${ }^{26}$

"The right to freedom of assembly is central to our constitutional democracy. It exists primarily to give a voice to the powerless. This includes groups that do not have a political or economic power, and other vulnerable persons. It provides an outlet for their frustrations. This right will, in many cases, be the only mechanism available to them to express their legitimate concerns. Indeed, it is one of the principal means by which ordinary people can meaningfully contribute to the constitutional objective of advancing human rights and freedoms. This is only too evident from the brutal denial of this right and all the consequences flowing therefrom under apartheid. In assessing the

\footnotetext{
Par 43.

24 Par 53.

25 Par 57.

26 Par 61.
} 
nature and importance of the right, we cannot therefore ignore its foundational relevance to the exercise and achievement of all other rights."

However, the court reasoned further that the importance of the limitation was also crucial because it served to protect members of society, especially those without the necessary resources to identify and pursue the perpetrators of riot damage which they have suffered. ${ }^{27}$ The court added further that the nature and extent of the limitation must not be exaggerated. ${ }^{28}$ The RGA does not prevent people from embarking on demonstrations, but imposes conditions in order to prevent damage to property and personal injury. In so doing, the RGA placed a presumption of liability on organisers of demonstrations for damages arising out of a demonstration. The effect of the presumption was alleviated by the possibility of organisers claiming from other wrongdoers with whom they are jointly and severally liable on the basis of the apportionment of damages. On the relation between the limitation and its purpose, the court found that the purpose of section 11 of the RGA was to afford victims of riot damage a viable legal recourse in the event that riot damage occurs. ${ }^{29}$ This way, an appropriate balance is struck between the right to assemble and the safety of people and property, ${ }^{30}$ and this balance could not have been achieved through any other means.

Broadly speaking, the SATAWU $v$ Garvas case is authority for the view that, although the courts recognise the importance of the right to freedom of assembly, the right may be limited in order to give effect to any law, civil or criminal, that seeks to protect the rights of the victims of violence during protests and strikes (that is, the non-protesters). Civil laws of this nature have been given a stamp of approval in SATAWU $v$ Garvas. It remains a subject of debate whether the criminal sanctions also aimed at protecting the rights of victims of violent protests would also be upheld. The likely attitude of the court or the line of reasoning the court is likely to take in the question of the development of the crime of public violence is canvassed in the topics that follow below.

\section{IS THE CRIME OF PUBLIC VIOLENCE FAILING TO ADEQUATELY PROTECT THE RIGHTS OF NON- PROTESTERS?}

The question for consideration in this instance is: On what grounds can it be said that the crime of public violence is failing to adequately safeguard the rights of non-protesters? This failure of the crime is evidenced by the following considerations: first, the increasing number of violent protests and strikes regardless of the existence of the crime, thus raising doubt as to its deterrent effect; ${ }^{31}$ second, the numerous instances where the rights of nonprotesters (particularly the rights to life, dignity, equality, as well as freedom

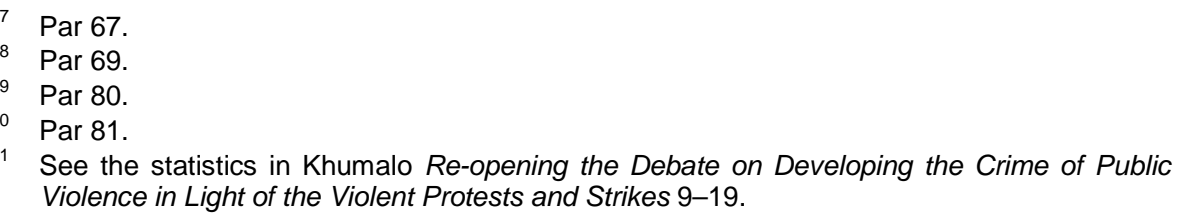


and security of the person) are violated during violent protests; ${ }^{32}$ third, the public perception of the crime as being almost irrelevant as it is hardly enforced: 33 fourth, the paucity of successful prosecutions for public violence ${ }^{34}$ fifth, the reluctance or the lack of a political will to pursue public violence charges $;{ }^{35}$ and that the sentences imposed on public violence offenders are trivial and hardly have a deterrent effect. ${ }^{36}$

There are certainly other possible explanations which could negate the above-named considerations as being evidence of the failure of the crime to safeguard the rights of non-protesters. ${ }^{37}$ To reconcile the foregoing, we must accept that it is nonetheless a possibility, irrespective of how remote, that the aforementioned factors could be construed as being indicative of the failure of the crime of public violence in protecting the rights of non-protesters. The crucial question is whether the alleged failure of the crime to adequately safeguard the rights of non-protesters renders the crime to fail to promote the spirit, purport and objects of the Bill of Rights. The answer to this question lies in the interpretation or meaning of the term "spirit, purport and objects of the Bill of Rights".

\section{DOES THE CRIME OF PUBLIC VIOLENCE FALL SHORT OF THE SPIRIT, PURPORT AND OBJECTS OF THE BILL OF RIGHTS AND THEREFORE REQUIRES TO BE DEVELOPED?}

The above question cannot be addressed without first ascertaining the meaning or interpretation of the term "spirit, purport and objects of the Bill of Rights". The term finds expression in the founding values of the Constitution provided for in section 1 and 7 of the Constitution. ${ }^{38}$ Put differently, the

32 Refer to the statistics and various incidents of violence and the violation of the rights of other people reported in newspaper articles which are cited in Khumalo Re-opening the Debate on Developing the Crime of Public Violence in Light of the Violent Protests and Strikes 9-19.

33 See "Heavy sentences for public violence convicts" 02 July 2013 SAnews.gov.za http:www.SAnews.gov.za/south-africa/heavy-sentences-public-violence-convicts (accessed 2014-05-24).

34 There is no doubt that with so much of violence taking place during protests and the police effecting so many arrests, the expectation is that there would be more than two reported judgments on public violence, these currently being the cases of $S v$ Whitehead 2008 (1) SACR 431 (SCA) and S v Le Roux 2010 (2) SACR 11 (SCA).

35 De Vos "Freedom of Assembly and its Limits: Constitutional Court" September 2009 Without Prejudice 5.

36 De Vos September 2009 Without Prejudice 4.

37 For instance, the lack of successful prosecutions for public violence could be explained by the difficulty of securing sufficient evidence in a crowd situation to secure a conviction for public violence - see liyayambwa "When Human Rights Congregate with Public Order Policing: A South African Perspective" 20122 International Journal of Humanities and Social Science 140 145. Furthermore, many public violence cases are dealt with in the Magistrates Court and never make it to the High Court, either on appeal or review because most of the times the accused persons are poor and they lack the necessary resources to pursue the case further. It is also possible that the acts of public violence for which the offenders are apprehended are not charged as public violence but rather as assault, malicious damage to property, arson or robbery.

38 See Currie and De Waal The Bill of Rights Handbook 57. See also De Vos et al South African Constitutional Law in Context 338. 
founding values of the Constitution constitute a backdrop against which the spirit, purport and objects of the Bill of Rights must be interpreted. There are two possible interpretations of the term "spirit, purport and objects of the Bill of Rights", which are both justified in terms of the founding values of the Constitution. One view on the interpretation of the term is that the courts tend to readily interpret the provisions of the Constitution in a manner that promotes the rights and interests of vulnerable groups in society which do not have a significant political voice. Generally, women and children fall under this category. ${ }^{39}$

The protection of women, as a vulnerable group in society, has been visible largely in the protection of their marital and property rights under customary and religious law. ${ }^{40}$ Similar sentiments of vulnerability were also successfully raised in the string of litigation towards the recognition of marital and other rights of gays and lesbians. ${ }^{41}$ Therefore, the victims of violence committed during protests and strikes could also be argued to constitute a vulnerable group in society without a significant political voice and therefore requires the protection of the law in a similar fashion as women, children, gays and lesbians. ${ }^{42}$

On the other hand, another view is that a proper interpretation of the term "spirit, purport and objects of the Bill of Rights" in light of the founding values of the Constitution is one that affords recognition to the injustices of the past and emphasise the sanctity of fundamental human rights, such as freedom of assembly, that were suppressed under the apartheid system in favour of state security. This interpretation is consistent with the view taken in various pre-constitutional, post-constitutional and foreign case law to the effect that the courts must be loath to uphold the laws and conduct that has the effect of restricting the fundamental right to freedom of assembly. ${ }^{43}$

The approach to choosing an appropriate interpretation or meaning of the term "spirit, purport and objects of the Bill of Rights" entails looking at the

See Masiya v Director of Public Prosecutions, Pretoria supra par 37.

40 In regard to the protection of the rights of women married by Muslim rites, see for instance Daniels v Campbell NO 2004 (5) SA 331 (CC); Hassam v Jacobs NO 2009 (5) SA 572 (CC); Ryland v Edros 1997 (2) SA 690 (C); and Amod v Multilateral Motor Vehicle Accidents Fund 1999 (4) SA 1319 (SCA). In regard to the protection of the rights of women married by Hindu rites, see Govender v Ragavayah [2009] 1 All SA 371 (D). In regard to the protection of the rights of women married in terms of African customary law, see Gumede $v$ President of Republic of South Africa 2009 (3) SA 152 (CC). See further Bhe v Magistrate, Khayelitsha; Shibi v Sithole; South African Human Rights Commission $v$ President of the Republic of South Africa 2005 (1) SA 580 (CC) in regard to the inclusion of women as heirs in terms of the rules of intestate succession.

41 See National Coalition for Gay and Lesbian Equality v Minister of Home Affairs 2000 (2) SA 1 (CC); Du Plessis v Road Accident Fund 2004 (1) SA 359 (SCA); Minister of Home Affairs v Fourie; and Lesbian and Gay Equality Project v Minister of Home Affairs 2006 (1) SA 524 (CC). See further National Coalition for Gay and Lesbian Equality and $v$ Minister of Justice 1999 (1) SA 6 (CC) in regard to the declaration of the crime of sodomy as unconstitutional on the basis that it unfairly discriminates against gay men.

42 The approach of depicting the victims of protest violence as a vulnerable group was also adopted in SATAWU $\vee$ Garvas.

43 See S v Turell 1973 (1) SA 248 (C); S v Budlender 1973 (1) SA 264 (C); South African National Defence Union v Minister of Defence 1999 (4) SA 469 (CC); S v Mamabolo 2001 (3) SA 409 (CC); In Re Manhumeso 1995 (1) SA 551 (ZS); and Seeiso v Minister of Home Affairs 1998 (6) BCLR 765 (LesCA). 
current jurisprudential articulations evident in case law dealing with the treatment of the right to freedom of assembly in light of the prevailing trend of violent protests which are often accompanied by the invasion of the various rights of non-protesters. To begin with, some of the cases which support the interpretation that preserves the right to freedom of assembly date back to the years of apartheid. ${ }^{44}$ At the time, the right to freedom of assembly did not enjoy constitutional protection. In fact, the right to freedom of assembly, among others, was heavily restricted for purposes of state security. It is therefore not surprising that the courts in $S v$ Turell and $S v$ Budlender felt so strongly about the right to freedom of assembly and the need for its protection.

The courts continued to emphasise the importance of the protection of the right to freedom of assembly even in the early period of the democratic era. ${ }^{45}$ This was also consistent with the approach in other jurisdictions (Zimbabwe and Lesotho) with similar assembly jurisprudence as South Africa. ${ }^{46}$ While South Africa's history of apartheid might have been a major reason for the protection of the right to freedom of assembly, one must also appreciate that most of the cases where the courts came out strongly in support of the protection of the right to freedom of assembly arose in the context of the interpretation of the provisions of legislation that empower the authorities to prohibit certain gatherings. ${ }^{47}$ Vigilance on the part of the courts in such cases is indeed required to guard against the abuse of power by the authorities.

The courts' position on the protection of the right to freedom of assembly seems to be different where the right is limited for purposes of protecting the rights of other people. It is a well-known fact that the culture of violent protests in South Africa has since re-emerged and, as a result of the violence, many of the rights of non-protesters have taken strain. This has led the courts to gradually change their outlook towards the right to freedom of assembly as evidenced by the cases of Fourways Mall (Pty) Ltd $v$ South African Commercial Catering and Allied Workers Union ${ }^{48}$ and SATAWU $v$ Garvas.

Therefore, given the jurisprudential shift outlined above, it follows that any law, civil or criminal, which seeks to protect the rights of non-protesters is consistent with the values of the Constitution, hence it promotes the spirit, purport and objects of the Bill of Rights. Therefore, the failure of the crime of public violence to adequately safeguard the rights of non-protesters, a vulnerable group in society, means that the crime is failing to promote the spirit, purport and objects of the Bill of Rights and therefore requires to be developed.

See $S$ v Turell supra; and $S$ v Budlender supra.

45 See South African National Defence Union v Minister of Defence South African National Defence Union supra; and $S$ v Mamabolo supra.

46 See In Re Manhumeso and Seeiso v Minister of Home Affairs supra.

47 See S v Turell supra; S v Budlender supra; In Re Manhumeso supra; and Seeiso v Minister of Home Affairs supra.

481999 (3) SA 752 (W). The effect of this decision is that section 17 of the Constitution and the Labour Relations Act 66 of 1995 does not extend to protect protesters from liability for assaults and other conduct that violates the rights of other people. 
To further enhance the argument for development, it is noteworthy that the development of the common law in general is important as it ensures that the common law is flexible to change with the social, moral and economic fabric of society and thereby continuously promote the spirit, purport and objects of the Bill of Rights.

The crime of public violence has also been evolving over the years through judicial interpretation and development. The judicial development of the crime is consistent with the principle of legality as there is clearly no extension of the definition of the crime to cover new conduct that was not previously covered. The crime has always been applicable in instances of protest or crowd violence. Its development would ensure that it executes its purpose to maintain public peace and order as well as to afford protection to the rights of non-protesters effectively, and thereby promote the spirit, purport and objects of the Bill of Rights.

It is also correct that the development of the crime of public violence would bring with it the advantage of eliminating any doubtful areas in the crime and afford an opportunity to fill whatever gaps there may be in the definition and elements of the crime. ${ }^{49}$ The overall result would be the improvement of the efficacy of the understanding of the meaning of the crime in curbing or deterring the scourge of violent protests and strikes and the accompanying invasion of the rights of other people, and thereby aid the crime's ability to promote the spirit, purport and objects of the Bill of Rights.

\section{IS THE RIGHT TO FREEDOM OF ASSEMBLY IN SECTION 17 OF THE CONSTITUTION APPLICABLE IN PUBLIC VIOLENCE CASES?}

Reliance on the argument that the development of the crime of public violence would unjustifiably limit the right to freedom of assembly in section 17 of the Constitution raises a question as to whether the said right is really implicated in public cases. It will be recalled that section 17 has its own internal modifiers to the effect that the right must be exercised "peacefully and unarmed". At first glance, a demonstration from which public violence is allegedly committed cannot be said to have been peaceful. ${ }^{50}$ Therefore, such a gathering should not fall within the protective ambit of section 17 of the Constitution. However, the effect of the court's decision in SATAWU $v$ Garvas is that the meaning of the word "peaceful" is restricted and a demonstration does not automatically become non-peaceful (such that the constitutional protection of the right to demonstrate of all the participants is

49 Snyman "Extending the Scope of Rape - A Dangerous Precedent: Note" 2007124 South African Law Journal 677-678.

50 This conclusion is drawn from the ordinary meaning of the word "peaceful", which is to say that a non-peaceful gathering or demonstration is one that leads to disorder or violence against property or a person, and an "armed" demonstration refers to a demonstration during which the demonstrators carry arms in the conventional sense of the word (i.e. guns, traditional weapons and other dangerous objects) - see Rautenbach "The Liability of Organisers for Damage Caused in the Course of Violent Demonstrations as a Limitation of the Right to Freedom of Assembly SATAWU v Garvas 20128 BCLR 840 (CC): Regspraak" 20131 Tydskrif vir die Suid-Afrikaanse Reg 151160. 
forfeited) simply because other members of the protesting crowd committed the acts of public violence. ${ }^{51}$

The situation in public violence cases is different from what transpired in SATAWU $v$ Garvas. This case concerned a situation whereby liability for riot damage was sought to be imputed on the union SATAWU. SATAWU was the bearer of the right to demonstrate. It follows that since SATAWU had not been shown to have failed to exercise its right peacefully or that it intended the march not to be peaceful, then its right to demonstrate remained constitutionally protected regardless of the fact that other participants in the march turned violent and, as a result, caused damage. It also follows that only those individuals who caused riot damage had not been peaceful. Therefore, had they been identified and sued for damages instead of SATAWU, those individuals would have been unable to defend themselves on the basis that the RGA's imposition of civil liability infringed their right to demonstrate because they would have forfeited the constitutional protection of their right.

On the contrary, criminal liability for public violence attaches only to those individuals who are identified and apprehended for engaging in unlawful acts that amount to the commission of the crime of public violence. Those individuals so apprehended would, at the time of the commission of public violence, not have been exercising their right to demonstrate peacefully. ${ }^{52}$ Therefore, in light of the decision in SATAWU $v$ Garvas, those individuals would forfeit their right to demonstrate, while the rest of the protesters who are peaceful in their intention and behaviour would retain the constitutional protection of their right to demonstrate.

There is no doubt that public violence cases would give the court's decision in SATAWU $v$ Garvas a practical application. These are cases that would compel the courts to find that an individual, by engaging in acts of public violence, was not acting peacefully and therefore forfeits his or her right to demonstrate. In closure, since the right to demonstrate is not implicated in public violence cases, the development of the crime of public violence cannot be opposed on the basis that it would infringe the right in section 17 of the Constitution.

51 See Rautenbach 2012 Tydskrif vir die Suid-Afrikaanse Reg 160-161. The writer provides examples of how in foreign jurisdictions the meaning of the words "peaceful" and "unarmed" have been restricted. These jurisdictions include Canada, the United States of America and Germany. Of note is the three-fold German approach to restricting word "peaceful" intrinsic in the right to freedom of assembly. First, when the intensity of the disturbance is alleged to render a gathering non-peaceful, what is required is for there to be violence and serious damage to property. Second, regarding the possibility of the occurrence of violence, at least a direct threat of violence must be present. Third, in respect of the different categories of individual participants, simply because some members of the crowd became violent does not mean that the demonstration is not peaceful such that the constitutional protection of the right to demonstrate of all the other participants is forfeited. The last approach is identical to the one which was adopted by the Constitutional Court in the SATAWU $v$ Garvas.

52 This is supported by Rautenbach's submission that some consensus exists among the German courts and writers that a gathering is not peaceful when it leads directly to disorder (oproer in Afrikaans) or violence against persons and property - Rautenbach 2012 Tydskrif vir die Suid-Afrikaanse Reg 160. 


\section{CHILLING EFFECT}

Assuming that the above conclusion is incorrect and that the right to freedom of assembly is indeed implicated in public violence cases, would the development of the crime of public violence have a "chilling" effect on the right to freedom of assembly, and thereby limit the said right? It will be recalled that in SATAWU $v$ Garvas, section 11(2) of the RGA was found to have limited the right to freedom of assembly for two reasons: first, compliance with the requirements of section 11(2) increased the cost of organising a demonstration; second, the section had the effect of inhibiting those poorly-resourced organisations from organising demonstrations. Both these considerations had the effect of "chilling" the exercise of the right to freedom of assembly.

It is difficult to conceive how the crime of public violence would have the same effect as section 11(2) of the RGA. The crime does not have any cost implications for anyone, let alone the organisers of gatherings and demonstrations. The organisers of demonstrations are not required to take any steps to prevent protesters from engaging in unlawful acts which might constitute public violence. The crime does not impose any conditions or restrictions on demonstrations. Consequently, no organisation can complain of being inhibited from embarking on a demonstration because of the existence or development of the crime of public violence. In essence, the crime of public violence only comes into effect when the constitutional right to demonstrate is abused and the rights of other people are violated.

Perhaps some weight could be given to Bishop's ${ }^{53}$ contention that the effect of the decision in SATAWU $v$ Garvas is that even the "indirect limitations that merely make it more difficult to protest" also limit the right to demonstrate and will have to be shown to be justifiable. In my view, the argument stemming from this line of reasoning is that the crime of public violence indirectly constrains the exercise of the right to demonstrate due to the inherent threat of incarceration and the resultant loss of personal liberty. Persuasive as the argument might seem, one cannot shake away the feeling that this argument is far-fetched. As a result, not much weight could be ascribed to it.

\section{IS THE LIMITATION JUSTIFIABLE IN TERMS OF SECTION 36 OF THE CONSTITUTION?}

Assuming further that the development of the crime of public violence has a "chilling" effect on the exercise of the right to freedom of assembly, thereby limiting the said right, the limitation would, upon engaging the inquiry in terms of section 36 of the Constitution, be reasonable and justifiable in an open and democratic society for purposes of protecting the constitutional rights of non-protesters. Section 36 of the Constitution provides that "[t]he rights in the Bill of Rights may be limited only in terms of law of general application to the extent that the limitation is reasonable and justifiable in an open and democratic society based on human dignity, equality and freedom, taking into account all relevant factors, including - (a) the nature of the right;

53 Bishop and Brickhill "Constitutional Law" 2013 Annual Survey of SA Law 150178. 
(b) the importance of the purpose of the limitation; (c) the nature and extent of the limitation; (d) the relation between the limitation and its purpose; and (e) less restrictive means to achieve the purpose".

\section{(a) The nature of the right}

The right to freedom of assembly has not lost the significance it has always carried. In actual fact, the need for free assemblies has become even more important especially now that South Africa is a democratic state. In a democracy, dialogue is an essential precursor to decision-making. Individual views are represented by organised formations, hence the need for legal recognition and protection of the right of individuals to organise themselves into these formations and then be able to express themselves freely. ${ }^{54}$ As a result, assemblies create a platform or an environment which is conducive for collective dialogue and deliberations. ${ }^{55}$ In this regard, the view of the court in $S v$ Turel/ ${ }^{6}$ becomes relevant:

"Freedom of speech and freedom of assembly are part of the democratic rights of every citizen of the Republic and Parliament guards these rights jealously for they are part of the very foundations upon which parliament itself rests. Free assembly is a most important right for it is generally only organised public opinion that carries weight and it is extremely difficult to organise it if there is no right of public assembly".

Furthermore, resort to protest action is a potent tool used by vulnerable groups in South Africa to communicate their concerns. Unlike in western countries where communities have an option communicate their concerns electronically through computers, televisions and newspapers, the vulnerable groups in South Africa do not have access to the media, thus leaving demonstrations their only available avenue to vent their frustrations.

Furthermore, the exercise of the right to assemble assists the Government to identify pressing issues in society in-between elections, thereby promoting Government accountability and responsiveness. ${ }^{58}$ It has also been observed that free assemblies contribute to a participatory democracy in terms of which the citizens are actively involved in public affairs. ${ }^{59}$ Therefore, free assemblies "create space for large, vocal social formations that service representative democracies; act as catalyst for debate; and enhance the legitimacy of the political processes by allowing for the articulation of minority views". ${ }^{60}$

\footnotetext{
54 Woolman in Woolman, Roux; Klaaren, Stein, Chaskalson, and Bishop (eds) Constitutional Law of South Africa (2005) 43-1. See also De Vos et al South African Constitutional Law in Context 550

55 Woolman in Woolman et al (eds) Constitutional Law of SA 43-2.

$56 S v$ Turell supra 256. See further the dictum of the court in SATAWU $v$ Garvas supra par 61 on the nature of the right to freedom of assembly quoted in par 3 above.

57 Woolman in Woolman et al (eds) Constitutional Law of SA 43-3.

58 Ibid.

59 De Vos et al South African Constitutional Law in Context 550.

60 Woolman in Woolman et al (eds) Constitutional Law of SA 43-21-43-22.
} 


\section{(b) The importance of the purpose of the limitation}

While the right to freedom of assembly is undoubtedly a very important right, the importance of the purpose of the limitation (that is, the development of the crime) is also as crucial. The limitation would serve to protect a vulnerable group in society that probably does not have the resources to pursue the organisers of protest action for damages and cannot even identify the perpetrators of violence in order to seek recourse against them.

\section{(c) The nature and extent of the limitation}

The nature and extent of the limitation must not be exaggerated. By no means does the crime of public violence prevent organisations or people in general from embarking on peaceful, yet meaningful and powerful demonstrations. Developing the crime of public violence affords only protection to the rights of the victims of violent protests and ensures that they are not left without a viable legal recourse for the protection of their rights, especially when they lack the necessary resources to pursue the organisers of demonstrations and cannot identify the perpetrators of violence.

\section{(d) The relation between the limitation and its purpose}

Given the nature and extent of the limitation discussed above, a proper balance is struck or between, on the one hand, the protection of the rights of non-protesters and, on the other hand, the exercise of the right to freedom of assembly. The fact that civil sanctions in terms of section 11 of the RGA already serve this purpose is no impediment to developing the crime of public violence to balance the scales even more.

\section{(e) Less restrictive means to achieve the purpose}

The crucial balance struck between the limitation and its purpose cannot be achieved through any other means.

It must be emphasised that the conclusion that the right to freedom of assembly in section 17 of the Constitution is most likely not to be implicated in public violence cases, that the development of the crime of public violence would most likely not have a "chilling" effect on the right to freedom of assembly and that the development of the crime would also constitutes justifiable limitation of the said right is not a blank cheque for the courts not to heed the call to approach with caution and restraint any limitation of the fundamental right to freedom of assembly.

\section{THREAT OF REBELLION}

A seemingly compelling argument against the development of the crime of public violence is that the limitation of the right to freedom of assembly, more than it is currently limited by the RGA, would threaten the country's young 
constitutional order. This argument emanates from Woolman's ${ }^{61}$ caution that the restriction imposed by the case of SATAWU $v$ Garvas on the right to freedom of assembly places the country at risk of the members of the public withdrawing their consent to the social contract which is manifest in the Constitution. The immediate result would be rebellion, and, if I may add, the resultant loss of legal order leading to a total state of anarchy. ${ }^{62}$ Woolman's contention is complemented by the following quote: "[v]iolence is seldom, if ever, spontaneous, but arises from a conviction that fundamental rights are denied". ${ }^{63}$

It seems that Woolman was reflecting on the events of the apartheid era, where every newly-enacted law which increasingly restricted assemblies was met with more fierce opposition from the public, thus leading to a breakdown of legal order in the country and a total state of anarchy. During apartheid, fundamental rights were denied and violence directed at persuading Government to recognise that fundamental human rights was rife.

It stands to reason that the undesirability of limiting the right to freedom of assembly any more than it is presently restricted cannot entirely be an impediment to the development of the crime of public violence, if that promotes the spirit, purport and objects of the Bill of Rights. It may certainly be a factor, but it cannot be decisive on its own. Furthermore, it is doubtful that the threat of rebellion, violence and anarchy would become greater should the right to freedom of assembly be limited further, which is a legally sound argument. It is actually tantamount to holding the courts ransom so as to reach a particular finding that is favourable to a specific segment of society, failing which, disorder would erupt.

\section{STIFLING OF DISSENT}

It can also be contended that the development of the crime of public violence bears the risk that the crime might be manipulated and utilised by those in authority to stifle dissent. This contention is based on a submission by Dlamini $^{4}$ who points out that the State's response to service-delivery protests has largely been intolerant and suppressive, and such action has seen peaceful protesters being placed in custody, assaulted and arbitrarily charged with the crime of public violence. Dlamini ${ }^{65}$ does provide some evidence of the alleged abuse of the crime to stifle dissent. Although the incidents of assault and detention of peaceful protesters cannot be said to occur frequently, one must acknowledge that such incidents do occur. To the extent that such manipulation and abuse occurs, it must certainly be

61 Woolman "My Tea Party, Your Mob, Our Social Contract: Freedom of Assembly and the Constitutional Right to Rebellion in Garvis v SATAWU (Minister for Safety \& Security, Third Party) 2010 (6) SA 280 (WCC)" 201127 South African Journal on Human Rights 346352.

62 Woolman 2011 South African Journal on Human Rights 352-353. Woolman cites as proof of the looming rebellion of the public the frequently dangerous trends which South African protests have assumed over the years.

63 Hjul "Restricting Freedom of Speech or Regulating Gatherings" 201346 De Jure 451456.

64 Dlamini "Mass Action and the Law - Can South Africa do Without the Regulation of Gatherings Act?" 20091 African Journal of Rhetoric 8698.

65 Dlamini 2009 African Journal of Rhetoric 98-99. 
condemned with the same degree of disapproval as the violence seen in most recent protests and strikes which culminate in the invasion of various rights of non-protesters.

\section{CRIMINAL SANCTIONS - NOT AN IDEAL REMEDY IN PUBLIC VIOLENCE CASES}

The development of the crime of public violence can also be opposed on the ground that there are certain indications which point to the possibility that criminal sanctions are not an ideal remedy in cases of public violence. One indication is that since apartheid is known for having made organising and holding gatherings a difficult and dangerous exercise which could, notably under the Internal Security Act $^{66}$ and the Riotous Assemblies Act, ${ }^{67}$ result in the incarceration of the organisers and participants if not done strictly according to the law, ${ }^{68}$ that gives an impression that resort to criminal sanctions in response to protests is associated with apartheid policing, and the Government would want to dispense with such a stigma.

Another indication could be that in those few instances where the perpetrators are prosecuted and convicted, the sanctions are trivial and hardly have a deterrent effect. ${ }^{69}$ De Vos ${ }^{70}$ attributes the imposition of light sentences to South Africa's apartheid history of undue restriction of assemblies, the brutality of the police in breaking up demonstrations, and that usually the demonstrators are poor and desperate group of people.

Furthermore, common sense would dictate that imprisonment is a very serious form of punishment. It involves a total loss of liberty of the convicted person. Indeed, it must be reserved for very grave circumstances. Terblanche $^{71}$ goes a step further and argues that the cases of public violence, especially those where there was no loss of life as in $S v L e$ Roux, ${ }^{72}$ present a perfect opportunity for the courts to apply restorativejustice methods and not impose an imprisonment term. Terblanche's argument further aids the observation that criminal sanctions are perhaps not the best response to public violence cases.

A further indication that criminal sanctions are perhaps not the ideal way to deal with protest violence is section 11 of the RGA which provides for the imposition of civil sanctions on organisers of demonstrations, and creates a reverse onus so to make it easier for the victims of protest violence to claim damages. This could be an indication that civil sanctions are the preferred remedy to aggrieved victims of protest violence. However, the civil-sanctions remedy operates against an adverse backdrop that might hinder its effectiveness. That backdrop is the possibility that not all victims of protest violence would have the financial means, or perhaps even the desire, to

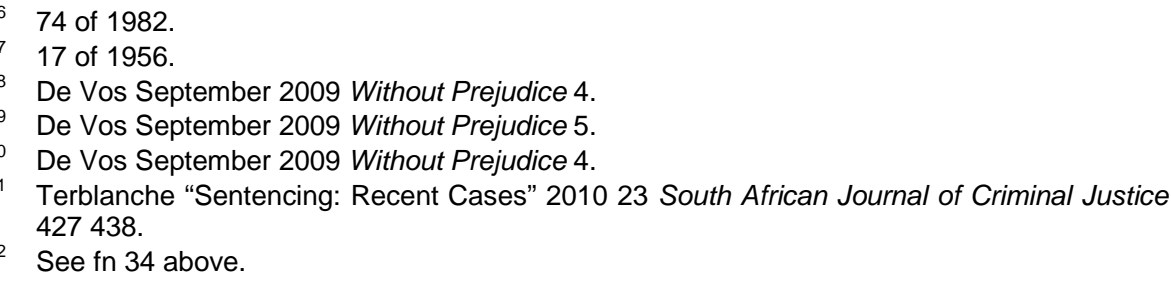


proceed by way of civil action against the organisers of demonstrations. ${ }^{73}$ It is also a possibility that not all the organisations or conveners of demonstrations as well as the participants therein would have the financial means to pay the amount claimed by the victims of protest violence as damages.

In any event, although the interests protected by the criminal and civil law are sometimes identical and even overlap, thereby giving rise to a claim in delict and a criminal charge, there are, however, some fundamental differences between the two, and the distinction must be maintained. ${ }^{74}$ For example, the criminal law falls under the branch of public law and is aimed at protecting the public interest, whereas the law of delict falls under the branch of private law and is aimed at protecting the individual (private) interest. ${ }^{75}$ Even the sanctions emanating from these two fields of law also differ. Civil sanctions are compensatory in nature (compensating and indemnifying the party who has suffered a loss, harm or damages as a result of a delict), while criminal sanctions are punitive in nature (they punish the offender for the breach of the public interest). ${ }^{76}$ Therefore, the mere fact that a remedy to the acts of public violence has been provided for in delict (either in terms of $s$ 11 of the RGA or the common law) does not mean that the same acts cannot also be punished in terms of the criminal law and vice versa. These two fields of law must co-exist. The one does not replace the other.

It would, therefore, seem that, in spite of the criminal sanctions being not so desirable, circumstances compel that criminal sanctions be invoked in order to protect the rights of non-protesters for the greater good of the community. No doubt the police have it within their means and resources to identify, pursue and successfully prosecute the perpetrators of violence. They are well resourced with equipment that can aid their identification of the perpetrators. It is noteworthy that many, if not all, public violence cases are proved on the identification and testimony of the police officers who were present at the scene. Their evidence can always be corroborated by other police officers who were also present at the scene.

In closure, the consolidation of the arguments on the question as to whether the crime of public violence fails to promote the spirit, purport and objects of the Bill of Rights leads to a positive conclusion. That means the crime of public violence falls short of the objectives of section 39(2) of the Constitution and thus requires to be developed in order to promote the spirit, purport and objects of the Bill of Rights. The next leg of the inquiry articulated in Carmichele $v$ Minister of Safety and Security ${ }^{77}$ turns on how the development of the crime must take place.

73 This sentiment is also echoed in liyayambwa 2012 International Journal of Humanities and Social Science 146.

74 Skeen in Joubert The Law of South Africa Vol VI par 11.

75 See Snyman Criminal Law 3-4; Neethling, Potgieter and Visser Law of Delict 6ed (2010) 7; and Midgley and Van der Walt "Delict" in Joubert The Law of South Africa Vol VIII, Part 1 2ed (2010) par 2.

76 Neethling et al Law of Delict 7.

77 See fn 10 above. 


\section{HOW MUST THE DEVELOPMENT TAKE PLACE?}

\section{Interpretation of the elements of the crime}

The history pertaining to the development of the crime of public violence illustrates that the crime has always been developed by the courts through revisiting and interpreting the elements of the crime, bearing in mind the changing social, moral and economic fabric of society and the constraints imposed by the principle of legality. The same approach was endorsed in $K$ $\checkmark$ Minister of Safety and Security ${ }^{78}$ in regard to the development of the vicarious liability principles in light of the values of the Constitution. The court held that, in essence, the purpose of section 39(2) of the Constitution is to ensure that the values of the Constitution are infused into the common law, and the approach thereto simply entails that the common-law principles be understood and applied within the normative framework of the Constitution.

The approach of the court in $S v$ Mlotshwa, ${ }^{79}$ although it was decided long before $K v$ Minister of Safety and Security, is nonetheless a good example of how the courts have interpreted the common-law crime of public violence with the view to instil certain values. In Mlotshwa the court can be argued to have interpreted the "serious dimensions" element of the crime of public violence in a manner that afforded recognition and protection to the fundamental right to strike. The court had to apply the crime of public violence in a strike situation so to punish and deter the violence, but at the same time it needed to accommodate the shift towards democracy and the recognition of basic human rights.

Today, South Africa confronts the increasing number of violent protests and strikes during which various rights of non-protesters are violated. In response thereto, the crime of public violence can be developed by approaching the interpretation of the elements of the crime, bearing in mind the values of the Constitution as well as the purpose of the crime to protect the rights of other people during protests and strikes. This way, the values of the Constitution and the spirit of the protection of the rights of non-protesters will be infused into the jurisprudence of the crime of public violence.

The answer to the question as to which element needs to be revisited and interpreted differently will depend on the facts of each case. In the absence of such facts, it is difficult to identify which of the elements of the crime need to be interpreted differently. However, it is noteworthy that the "serious dimensions" element, despite being central to the determination of whether or not certain conduct amounts to the commission of the crime of public

\footnotetext{
Ibid.

1989 (4) SA 787 (W). In Mlotshwa the striking workers barred the non-striking workers from entering the premises of the employer. They surrounded the vehicle transporting the nonstriking workers and opened its doors, shouting and hitting the vehicle. The court found that the dimensions of the fracas were not sufficiently serious since neither of the striking workers were armed, nor was there any injury to the non-striking workers or their property and the incident lasted for merely seven seconds. The court expressed further that the accused were on a lawful strike and the courts should be careful not to make adverse inroads into the right of workers to strike by classifying conduct during a strike as public violence.
} 
violence ${ }^{80}$ remains a largely vague criterion. Given the vagueness thereof, the element places itself at the top of the list of the elements which may be interpreted differently and therefore be utilised as a conduit for infusing the values of the Constitution and the spirit of the protection of the rights of nonprotesters into the jurisprudence of the crime of public violence.

\section{Imposition of tougher sanctions}

Another way of developing the crime of public violence is to revisit the sentences ${ }^{81}$ meted out for the crime and ensure that they adequately reflect society's condemnation of the violence and the invasion of the rights of nonprotesters. This has been a practice commonly relied upon by the South African courts ${ }^{82}$ and they have been doing so despite research evidence to the effect that there is no relation between the imposition of tougher sanctions and crime control or deterrence. The flexibility to adjust sentences in public violence cases can be justified under the "Zinn triad" element of the seriousness of the crime and the interests of society, mitigated by the personal circumstances of each offender. ${ }^{83}$

The pattern of violent protests has notably been on the rise from the year 2004. It has escalated over the years and has now become more and more invasive of the rights of other people. Logic would dictate that, as violence becomes more prevalent and destructive of the rights of other people, the more serious the crime becomes in the eyes of society, and it becomes more in the interests of society that the punishment for the crime be harsher.

In the event that the call for harsher punishment is heeded, the question then arises what kind of punishment would be sufficiently harsh for public violence offenders. The starting point would be to point out that in $S v$ Dingiswayo, ${ }^{84}$ the court held that it is no longer appropriate to impose a wholly suspended sentence or a fine in public violence cases. The norm is thus to sentence the offenders to some imprisonment term, suspended as the court deems appropriate. The precedent set in $S v$ Dingiswayo, a case which was decided at the peak of the uprisings against the apartheid system during which public violence was rife, understandably disintegrated at the inception of democracy. The precedent was hardly of any use between the year 1994 and 2004, the latter being the year in which statistics began to reflect an increasing trend in violent protests.

80 In this regard, see Khumalo Re-opening the Debate on Developing the Crime of Public Violence in Light of the Violent Protests and Strikes 43-45.

81 For a discussion of the sentencing principles for the crime of public violence, see Khumalo Re-opening the Debate on Developing the Crime of Public Violence in Light of the Violent Protests and Strikes 46-50.

82 See, inter alia, S v Dingiswayo 1985 (3) SA 75 (Tk); and S v Samaai 1986 (4) SA 860 (C).

83 Sentences for public violence offenders have been omitted from the minimum-sentences legislation (s 51(2)(c)(i)-(iii) of the Criminal Law Amendment Act 105 of 1997), save for those instances where the accused had with him a firearm which was intended for use during the commission of public violence, amongst other offences. It follows that the sentencing discretion in respect of the crime of public violence lies with the courts, guided by the principles encapsulated in S v Zinn 1969 (2) SA 537 (A) 54 (the Zinn triad). The Zinn triad consists of the crime, the offender and the interests of society.

84 See fn 82 above. 
Now that the violent protests are, once again, common phenomena, the precedent in $S \vee$ Dingiswayo is worthy of being considered once more. Adopting the same line of reasoning as in $S v$ Dingiswayo, it is clear that the seriousness of the crime of public violence is such that it warrants that the offender serves at the very least some imprisonment term, no matter how short, but subject to the minimum imprisonment term permitted in law. ${ }^{85} \mathrm{~A}$ wholly suspended sentence or a fine is not desirable. The same reasoning can be applied in determining the portion of a prison term that should be suspended.

The next hurdle would be to give an indication of the imprisonment term that would be proportional to the seriousness of the crime of public violence and would serve the interests of society. If the Whitehead ${ }^{86}$ and Le Roux ${ }^{87}$ cases, being the most recent reported judgments on public violence, are anything to go by, given the fact that these cases did not emanate from instances of violent protests, they provide a sentencing guideline for public violence in the region of five to six years, suspended as the court deems appropriate. However, such a sentence would be reserved for the extreme cases of public violence, such as those cases where one or more person was killed or where there was severe damage to property.

Therefore, taking into account the historical significance of the right to freedom of assembly and its importance to the working class and the poor and illiterate members of society, the imposition of a prison sentence in the region between the minimum four days permitted in law and five to six years (reserved for the most extreme cases of protest violence), suspended as the court deems necessary, is apt for the expression of society's condemnation of the violence and the protection of the rights of the non-protesters which are severely compromised during protests. Anything above this range should be supported by extremely compelling facts.

The financial cost of sentencing public violence offenders as such is far outweighed by the benefit to society. The financial concern is also vitiated by the inevitably short imprisonment terms the court is likely to impose because not all public violence cases would warrant a five- to six-year imprisonment term. Even in those extreme cases, the court may suspend the sentence as it deems appropriate, thus reducing the time to be spent by the convicted offender in a prison facility. The possibility of the offender being granted parole before completing his or her prison term (which invariably would have been as short term) also vitiates the financial concern.

\section{CONCLUSION}

The examination of the academic views, arguments, opinions, case law and other relevant authority undertaken in the present paper points to a jurisprudential shift away from the protection of the fundamental right to freedom of assembly in cases, where the limitation of the said right serves to

85 See s 284 of the Criminal Procedure Act 51 of 1977 which prescribes a minimumimprisonment duration of at least four days unless the accused is sentenced to detention until the rising of the court.

86 See fn 34 above.

Ibid. 
uphold those laws which seek to protect the rights of non-protesters or victims of violent protests, a vulnerable group in society. The effect of the jurisprudential shift is that, should the constitutional validity of any law, civil or criminal, that seeks to protect the interests or rights of non-protesters be in issue in the future, the courts will most likely uphold the constitutional validity of that law. For present purposes, this means that there is a case for challenging the constitutional validity of the crime of public violence on the ground that its apparent failure to adequately safeguard the rights of nonprotesters, means that the crime fails to promote the spirit, purport and objects of the Bill of Rights and therefore requires to be developed.

The development of the crime of public violence may be effected by way of interpreting the elements of the crime against the backdrop of the values of the Constitution and in the spirit of the purpose of the crime to adequately safeguard the rights on non-protesters. The vagueness of the "serious dimensions" element in the definition of the crime of public violence can be used as a conduit through which the values of the Constitution may be infused into the jurisprudence of public violence. Another approach to developing the crime entails revisiting the sentences imposed on public violence offenders in order to ensure that they reflect society's condemnation of the violence and the invasion of the rights of other people. In this regard, any other punishment short of imprisonment has been shown to be no longer apt for purposes of punishing those who are convicted of public violence. 